\title{
ASSESSMENT OF GENOTOXICITY AND DEPURATION OF ANTHRACENE IN THE JUVENILE COASTAL FISH Trachinotus carolinus USING THE COMET ASSAY
}

\author{
Fabio Matsu Hasue*, Maria José de Arruda Campos Rocha Passos, Thaís da Cruz Alves dos Santos, \\ Arthur José da Silva Rocha, Caroline Patrício Vignardi, Priscila Verônica Sartorio, \\ Vicente Gomes and Phan Van Ngan
}

Instituto Oceanográfico da Universidade de São Paulo

(Praça do Oceanográfico, 191, 05508-120 São Paulo, SP, Brasil)

*Corresponding author: fabiomh@usp.br

\section{A B S TR ACT}

\begin{abstract}
In the environment, anthracene is characterized as being persistent, bioaccumulative and toxic to aquatic organisms. Biotransformation of xenobiotic substances, such as anthracene, produces reactive oxygen species that may induce DNA strand breaks. The aim of the present study was to evaluate the DNA damage in juvenile $T$. carolinus exposed to different concentrations $\left(8,16\right.$ and $\left.32 \mu \mathrm{g} . \mathrm{L}^{-1}\right)$ of anthracene for $24 \mathrm{~h}$ in the dark then subsequently allowed to depurate in clean water for different periods of time $(48,96$ or $144 \mathrm{~h}$ ) using the comet assay. Our results show that anthracene is genotoxic to $T$. carolinus and that DNA damage was dose- and depuration/time- dependent. Anthracene genotoxicity was observed in all experimental concentrations. Depuration seemed to be more efficient in fish exposed to the lowest anthracene concentration and maintained in clean water for $96 \mathrm{~h}$.
\end{abstract}

\section{R ESUMO}

\begin{abstract}
Ambientalmente, o antraceno é considerado persistente, bioacumulativo e tóxico para organismos aquáticos. A biotransformação de substâncias xenobióticas, como o antraceno, produz espécies reativas de oxigênio que podem agir sobre o DNA. O objetivo deste trabalho foi avaliar o dano ao DNA em $T$. carolinus expostos a diferentes concentrações de antraceno $\left(8,16\right.$ e $\left.32 \mu \mathrm{g} . \mathrm{L}^{-1}\right)$ por $24 \mathrm{~h}$ no escuro e subsequentemente mantidos em água limpa para depuração por três diferentes períodos de tempo (48, 96 e $144 \mathrm{~h})$ através de ensaio cometa. Os resultados obtidos demonstram que o antraceno é genotóxico para T. carolinus e o dano ao DNA foi dose- e tempo de depuraçãodependente. A genotoxicidade do antraceno foi detectada nas três concentrações utilizadas. A depuração pareceu ser mais eficiente nos peixes expostos a menor concentração de antraceno e mantidos por $96 \mathrm{~h}$ em água limpa.
\end{abstract}

Descriptors: Polycyclic aromatic hydrocarbons (PAH), Anthracene, DNA damage, Reactive oxygen species (ROS), Marine fish.

Descritores: Hidrocarbonetos policíclicos aromáticos (HPA), Antraceno, Dano ao DNA, Espécies reativas de oxgênio (EROS), Peixe marinho.

\section{INTRODUCTION}

Coastal organisms are frequently exposed to anthropogenic contaminants originating from untreated sewage and/or the influx of organic pollutants (PELLETIER et al., 2006). Among the organic pollutants found in coastal regions, natural and anthropogenic polycyclic aromatic hydrocarbons (PAHs) are widely distributed in the environment (BOWLING et al., 1983). Volcanoes, forest fires, burning wood, combustion of petroleum fuels, discharge of industrial and domestic wastewater and the leakage of toxic residue are all possible sources of PAHs input into the environment (MCELROY et al.,
1989; UNITED STATES, 1995; MEDEIROS; BÍCEGO, 2004). Many of these pollutants are hydrophobic and can be deposited in coastal sediment in areas near pollution sources (BEDDING et al., 1983; KIENE; CAPONE, 1984; MEDEIROS et al., 2005) and incorporated into the organisms that live in the water column and/or on the seabed. The toxicity of petroleum and its derivatives is largely attributed to its soluble fraction which contains polar compounds of low molecular weight (PACHECO; SANTOS, 2002). These compounds, such as the monochromatic hydrocarbons (benzene, toluene and xylene) and PAHs (naphthalene and anthracene) are extremely toxic, carcinogenic and mutagenic (LEE; PAGE, 1997; PACHECO; SANTOS, 2002). PAHs affect organisms 
by different pathways, the parental and those photomodified compounds can act via metabolic activation and when taken up on the body surface of organisms PAHs can act as photosensitizer in the presence of ultraviolet radiation (UVR). In both cases the damage to the organism is related to the production of reactive oxygen species (ROS) that are highly reactive and capable of oxidizing many biological macromolecules (TOYOOKA; IBUKI, 2007). In the environment, anthracene (ANT) is characterized as being persistent, bio-accumulative and toxic to aquatic organisms (EUROPEAN CHEMICAL AGENCY, 2008). Unlike other PAHs, ANT is not classified by The International Agency for Research on Cancer (IARC) as carcinogenic to human beings (UNITED STATES, 1995). ANT, when photo-modified by UVR, gives rise to a complex mixture comprising more than 20 products, including anthraquinone, hydroxianthraquinone, benzoic acid and phenols (MALLAKIN et al., 2000). Photo-modified ANT may be cytotoxic (SCHIRMER et al., 1998; CHOI; ORIS, 2003), highly phototoxic (BOWLING et al., 1983; ORIS; GIESY., 1987), can break down proteins and DNA (TOSHIMA et al., 2004; HASEGAWA et al., 2006) and also induces changes in cellular structures in the skin and gills of fish (ORIS; GIESY, 1985). Biotransformation is the process by which fish and other organisms eliminate xenobiotic substances, such as ANT. This process involves the formation of metabolic products, ROS, that may induce DNA strand breaks since they are able to modify the chromosome structure (clastogenicity) and the sequence of base pairs of DNA (mutagenicity), and promote the incomplete repair of DNA adducts (ALSABTI; METCALFE, 1995; DI GIULIO et al., 1995; ULUPINAR; OKUMUS, 2002; AKCHA et al., 2003; LEE; STEINNERT, 2003).

The single cell gel electrophoresis, commonly known as the comet assay, is an efficient tool for evaluating the effects of toxic substances on the DNA of aquatic organisms. It is a sensitive and relatively quick method that can be used in almost all eukaryotic cells to evaluate genotoxicity in animals, indicating the degree of damage to DNA (FRENZILLI et al., 2009). The results of the comet assay indicate that the higher the genotoxic potential, the greater the DNA damage revealed by the extension of the comet tail formed by the DNA fragments (COTELLE; FÉRARD, 1999).

The Carangidae family includes a number of economically important fish which are abundant in tropical and subtropical waters (CRABTREE et al., 2002). According to Menezes and Figueiredo (1980), some species of the genus Trachinotus, among them Trachinotus carolinus, are very common on the Atlantic coast from the southern United States to northern Argentina. The fish selected for this study,
Trachinotus carolinus (Actinopterygii, Carangidae), can tolerate different environmental conditions (JORY et al., 1985), is easy to catch and easy to maintain in captivity (SANTOS et al., 2006). T. carolinus has an opportunistic trophic strategy and wide diet spectrum based on crustaceans (Decapoda and Cirripedia), cephalochordates, polychaetes and others (NIANG et al., 2010). This feeding habit can contribute to the ingestion of many organisms that may have been previously contaminated. Moreover, it is being used as a sentinel organism for genotoxicity of PAHs and other pollutants in our laboratory (SANTOS et al., 2006; ROCHA et al., 2012). The aim of the present study was to evaluate the DNA damage in juvenile $T$. carolinus exposed to different concentrations of anthracene for a specific period then subsequently allowed to depurate in clean water for different periods of time using the comet assay.

\section{Material And Methods}

Preparation of working solutions: This study used ANT (Sigma-Aldrich ${ }^{\circledR}$ CSA 120-12-7), molecular weight $178.22 \mathrm{~g}$, diluted in PA ethanol to obtain a stock solution with a concentration of 0.32 g. $\mathrm{L}^{-1}$. Then, aliquots of this solution were diluted $1: 1$ and 1:3 for solutions of 0.16 and 0.08 g.L $\mathrm{L}^{-1}$, respectively. Aliquots of $100 \mu \mathrm{L}$ of each of these solutions were diluted in one liter of sea water to prepare the working solutions at concentrations of 32 , 16 and $8 \mu \mathrm{g} . \mathrm{L}^{-1}$. The choice of ANT concentrations was based on studies involving the exposure of fish to ANT solutions (BOWLING et al., 1983; ORIS; GISEY., 1985, 1987). Solutions of ANT and ethanol were replaced after 12 hours and at the end of $24 \mathrm{~h}$ each group was transferred to clean water.

Capture and maintenance of fish: Seventyfive juveniles of $T$. carolinus, with an average length of $42.7 \pm 3.3 \mathrm{~mm}$ and weight of $0.9 \pm 0.2 \mathrm{~g}$ (Table 1), were collected at the Lázaro and Enseada beaches (Ubatuba, SP, Brazil). To minimize the stress of capture the fish were maintained for a minimum of 10 days in a $500 \mathrm{~L}$ tank filled with aerated and filtered seawater before being used for experiment. The temperature, salinity and $\mathrm{pH}$ of the water were measured daily and maintained at $23 \pm 2^{\circ} \mathrm{C}, 35 \pm 1 \mathrm{PSU}$ and $\mathrm{pH}=8$, respectively. The fish were fed ad libitum with commercial fish food (45\% protein) but the supply was withdrawn 24 hours before the start of the experiments. The photoperiod was set at a $12 \mathrm{~h}$ light/dark cycle.

Exposure to anthracene: The fish were transferred from the maintenance shelter to the laboratory under controlled conditions two days before the beginning of the experiments. The temperature was maintained at $22 \pm 1^{\circ} \mathrm{C}$ and salinity at $35 \pm 1$ PSU. For each of three depuration periods, a batch of five 
groups, each of five fish, was used. Three groups of each batch were exposed to ANT with nominal concentrations of 8,16 and $32 \mu \mathrm{g} . \mathrm{L}^{-1}$ for ANT uptake; one group was exposed to water with ethanol; and the last one was kept in ANT-free seawater to be used as solvent control (SCtrl) and water control (WCtrl), respectively. The exposure was undertaken in a $40 \mathrm{~L}$ glass tank for $24 \mathrm{~h}$ in the dark to prevent any incidence of UVR and the ethanol level was kept at $0.01 \%$ in all the experimental groups, except the water control.

Depuration: After the $24 \mathrm{~h}$ period, the fish of each treatment were transferred to a $40 \mathrm{~L}$ tank with clean water for depuration (RAND, 2008) for 48, 96 or $144 \mathrm{~h}$. The water was fully renewed every $24 \mathrm{~h}$ by means of a continuous flow system. At the end of each period in clean water, fish of groups of one batch were removed from the aquaria for blood samples to perform the comet assay. The photoperiod was set at a $12 \mathrm{~h} \mathrm{light/dark} \mathrm{cycle} \mathrm{with} \mathrm{fluorescent} \mathrm{light.} \mathrm{The} \mathrm{level}$ of ultraviolet radiation (UVR $<0.001 \mu \mathrm{W} . \mathrm{cm}^{-2}$ ) of this kind of illumination is considered negligible (HATCH; BURTON, 1999).

Comet Assay: All chemicals without makers mentioned in the text were purchased from OMerck KGaA (Darmstadt, Germany). In this study the alkaline comet assay (SINGH et al., 1988) was conducted on the basis of the protocols of Tice et al. (2000) and Gontijo and Tice (2003) with modifications as described below. Ten microliters of blood from each fish were diluted in phosphate buffered saline (PBS, pH 7.4), then twenty microliters of this suspension were mixed with $120 \mu \mathrm{L}$ of gel of $1 \%$ low melting point agarose (Sigma-Aldrich ${ }^{\circledR}$ CSA 9012-36-6) dissolved in PBS and placed on a glass slide previously coated with a thin layer of $1.5 \%$ normal melting point agarose (Sigma-Aldrich ${ }^{\circledR}$ CSA 9012-36-6) gel. A cover slip was used to spread this suspension of blood and gels, which was then allowed to solidify at $4{ }^{\circ} \mathrm{C}$ in the dark for $20 \mathrm{~min}$., over the slide. Then the cover slips were removed and the slides were immersed in a lysing solution $(2.5 \mathrm{M}$ $\mathrm{NaCl}, 100 \mathrm{mM} \mathrm{Na} 2$ EDTA, $10 \mathrm{mM}$ Tris, $\mathrm{pH} \mathrm{10,} \mathrm{Triton}$ $\mathrm{X}-100$ and DMSO 10\%) for two hours at $4{ }^{\circ} \mathrm{C}$. They were then rinsed with distilled water for complete removal of the lysing solution. For DNA unwinding, slides were placed in the electrophoresis container and immersed for 5 minutes in a freshly prepared electrophoresis buffer solution $(300 \mathrm{mM} \mathrm{NaOH}, 1 \mathrm{mM}$ EDTA, pH > 13) at $4{ }^{\circ} \mathrm{C}$. Electrophoresis was performed at $4{ }^{\circ} \mathrm{C}$ with a voltage and amperage of 0.80 V.cm ${ }^{-1}$ and $230 \mathrm{~mA}$, respectively, for 20 minutes. The slides were then neutralized by twice immersing them in a neutral buffer ( $0.4 \mathrm{M}$ Tris, $\mathrm{pH} 7.5)$ for 15 minutes each. At the end, the slides were immersed in $100 \%$ ethanol at $4{ }^{\circ} \mathrm{C}$ for two hours and allowed to air-dry at room temperature. The slides were stained with silver nitrate following the procedure described in the study by García et al. (2004).

Analysis of DNA damage: Images of comets were photographed using a SAMSUNG SDF 312® digital camera attached to a Nikon ${ }^{\circledR}$ optical microscope and supported by the Ulead Video Studio 7 SE Basic $®$ software for the digitalization of the images. Using $20 \mathrm{X}$ magnification, one hundred comets were photographed in different regions of the slides, visually analyzed and classified into five classes from 0 to 4 , depending on the degree of DNA damage as described by Gomes et al. (2012). Class 0 represents undamaged DNA, and class 4 corresponds to comets with maximum damage (Fig. 1). The damage index (DI) was calculated as the sum of the products of the multiplication of the number of comets $(\mathrm{N})$ of each class and the denominator digit of the class: $\mathrm{DI}=0 .(\mathrm{N}$ Class 0$)+1 .(\mathrm{N}$ Class 1$)+2 .(\mathrm{N}$ Class 2$)+3$. ( $\mathrm{N}$ Class 3$)+4$. ( $\mathrm{N}$ Class 4$)$. Values of DI vary from 0 , when all comets are of class 0 , to 400 when all comets are of class 4 .

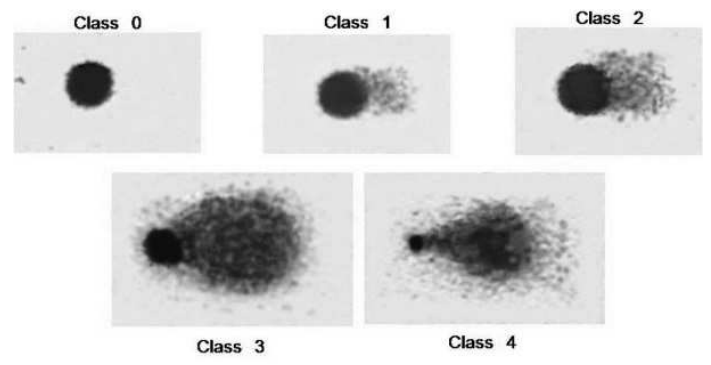

Fig. 1. Class 0. No damage - head is large and intact; comet without tail. Class 1. Slight damage - head is large and little affected; short tail whose length is less or equal to one head diameter; tail width is less than one head diameter. Class 2. Medium damage - head is large and little affected; short tail whose length is somewhere between one to two head diameters; tail width is less than one head diameter. Class 3. Extensive damage - head is reduced; long and large tail; tail length is somewhere between two and three head diameters; tail width is somewhere between two to three head diameter. Class 4. Severe damage - head is greatly reduced; long and large tail whose contour is difficult to determine due to disperse of small DNA fragments

Statistical analysis: The data analyses were performed using Statistica 7 (Stat Soft Inc.) software. Data were presented as means and standard errors. After normality and homogeneity of variance tests, nonparametric ANOVA Kruscal-Wallis was conducted and multiple comparison Newman-Keuls were used to identify groups with differences (ZAR, 1996). Differences were considered significant at $\mathrm{p}<$ 0.05 . 
Table 1. Mean of total length (TL), mass (M) and standard error $( \pm$ SE) of the fishes exposed to three concentrations of anthracene $\left(8,16\right.$ and $\left.32 \mu \mathrm{g} . \mathrm{L}^{-1}\right)$ and maintained in clean water for 48 (G 48), 96 (G 96) and 144 (G144) h for depuration. Corresponding control groups, WCtrl - water control and SCtrl - solvent control.

\begin{tabular}{lllllll}
\hline \hline \multicolumn{3}{c}{} & \multicolumn{3}{c}{ TL $(\mathbf{m m}) \pm$ SE } & \multicolumn{3}{c}{ M (g) \pm SE } \\
\hline & $\mathbf{G ~ 4 8}$ & G 96 & G 144 & G 48 & G 96 & G 144 \\
WCtrl & $47.0 \pm 2.19$ & $51.4 \pm 2.34$ & $46.4 \pm 2.32$ & $1.43 \pm 0.21$ & $1.46 \pm 0.18$ & $1.11 \pm 0.17$ \\
SCtrl & $51.6 \pm 2,23$ & $49.4 \pm 3.19$ & $47.2 \pm 2.13$ & $1.62 \pm 0.20$ & $1.31 \pm 0.21$ & $1.24 \pm 0.17$ \\
$\mathbf{8 ~ \mu g . L ^ { - 1 }}$ & $45.0 \pm 1,26$ & $45.3 \pm 1.11$ & $50.0 \pm 2.07$ & $1.06 \pm 0.09$ & $1.00 \pm 0.09$ & $1.46 \pm 0.21$ \\
$\mathbf{1 6} \boldsymbol{\mu g . L ^ { - 1 }}$ & $47.4 \pm 2,40$ & $48.4 \pm 2.25$ & $56.0 \pm 2.43$ & $1.16 \pm 0.16$ & $1.30 \pm 0.16$ & $1.88 \pm 0.25$ \\
32 $\boldsymbol{\mu g . L ^ { - 1 }}$ & $51.0 \pm 1,97$ & $48.4 \pm 1.91$ & $51.8 \pm 1.32$ & $1.33 \pm 0.17$ & $1.19 \pm 0.13$ & $1.55 \pm 0.16$ \\
\hline
\end{tabular}

\section{RESULTS}

All the results described below are given in Figure 2. After the depuration period of $48 \mathrm{~h}$, the DI in groups exposed to ANT are significantly higher $(\mathrm{p}<$ $0.01 ; \mathrm{H}=18.93$ and $\mathrm{p}<0.001$ ), averaging about 170 and 130 times more than the DI in the water and solvent controls, respectively. There were no significant differences between the DI of the controls or between those of the groups exposed to different concentrations of ANT solution.

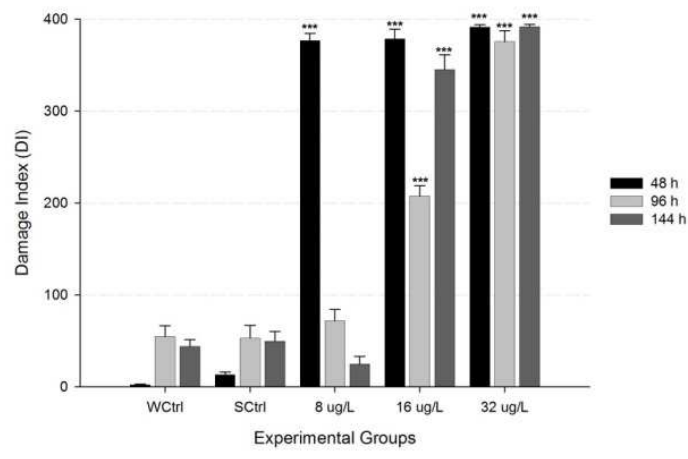

Fig. 2. Damage Index (DI) of DNA of $T$. carolinus exposed to three concentrations of anthracene, 8,16 and $32 \mu \mathrm{g} . \mathrm{L}^{-1}$, for 24 hours in darkness and subsequently maintained in clean water for 48,96 and $144 \mathrm{~h}$ for depuration. Data were presented as mean $(\mathrm{n}=5)$ and standard error. $* * * p<0.001$; Level of statistical difference between DI of groups exposed to ANT and DI of their corresponding controls groups; WCtrl - water control; SCtrl - solvent control.

As for fish from the $96 \mathrm{~h}$ group, the DI of fish exposed to ANT at concentrations of 16 and 32 $\mu \mathrm{g} . \mathrm{L}^{-1}$ were significantly different $(\mathrm{p}<0.01 ; \mathrm{H}=$ 17.18 and $p<0.001$ ) from each other and also from the DI of the WCtrl, SCtrl and $8 \mu \mathrm{g} . \mathrm{L}^{-1}$ groups. There were no significant differences between the DI of the WCtrl, SCtrl and $8 \mu \mathrm{g} . \mathrm{L}^{-1}$ groups. The DI of the 32 $\mu \mathrm{g} . \mathrm{L}^{-1}$ group is approximately twice and four times higher than those of the 16 and $8 \mu \mathrm{g} . \mathrm{L}^{-1}$ groups, respectively.

After the period of $144 \mathrm{~h}$ in clean water the DIs of the groups exposed to the two highest ANT concentrations (16 and $32 \mu \mathrm{g} . \mathrm{L}^{-1}$ ) were significantly different $(H=19.77$ and $p<0.001)$ from each other and from those of WCtrl, SCtrl and $8 \mu \mathrm{g} \cdot \mathrm{L}^{-1}$ (p < $0.01)$. In the $16 \mu \mathrm{g} . \mathrm{L}^{-1}$ group the DI increased $(\sim 60 \%)$ after $144 \mathrm{~h}$ compared with $96 \mathrm{~h}$ of depuration. However, the DIs after 96 and $144 \mathrm{~h}$ were not significantly different in the $32 \mu \mathrm{g} . \mathrm{L}^{-1}$ group.

The WCtrl and SCtrl groups after depuration periods of $96 \mathrm{~h}$ and $144 \mathrm{~h}$ showed a higher DI than those in the $48 \mathrm{~h}$ period. However, the DIs of these groups in the three periods are $10 \%$ lower than the maximum value (400) that the DI may reach. In the WCtrl group, the DI of the $48 \mathrm{~h}$ of depuration was significantly different from the DIs of $96 \mathrm{~h}(\mathrm{p}<0.01)$ and $144 \mathrm{~h}(\mathrm{p}<0.05)$. The DI of the SCtrl group at $48 \mathrm{~h}$ of depuration was significantly different from those at 96 and $144 \mathrm{~h}(\mathrm{p}<0.05)$; however, the results of these two last periods were not different from each other. The DIs of the 8 and $16 \mu \mathrm{g} . \mathrm{L}^{-1}$ groups were significantly different as between the periods of depuration. The $8 \mu \mathrm{g} . \mathrm{L}^{-1}$ groups showed a pronounced reduction in DI $(p<0.01)$ by reason of the time they remained in clean water, representing more than $90 \%$ of the $144 \mathrm{~h}$ period. At the intermediate concentration of $16 \mu \mathrm{g} . \mathrm{L}^{-1}$ the reduction in the DI was significant after $48 \mathrm{~h}$ of depuration ( $<<0.01$ ), reaching $45 \%$ after $96 \mathrm{~h}$. The DI after $144 \mathrm{~h}$ increased and reached the DI values seen at $48 \mathrm{~h}$ of depuration. There was no reduction in DNA damage in the $32 \mu \mathrm{g} . \mathrm{L}^{-1}$ group by reason of the periods of depuration. The DI values of the group remain close to 400 during all the periods in clean water. 


\section{Discussion}

Anthrecene is a common contaminant of estuaries, coastal areas and other aquatic ecosystems. The concentrations used in the present study can be considered environmentally realistic since they are lower than the aqueous solubility range $\left(<35 \mu \mathrm{g} . \mathrm{L}^{-1}\right.$ at $25^{\circ} \mathrm{C}$ ) of the substance (NEFF, 1979), and have been found in sediments and water columns in estuaries polluted with petrochemical products. For example, anthracene concentrations of $32 \mu \mathrm{g} / \mathrm{g}$ of organic content (OC) have been found in sediments of Santander Bay, Spain (VIGURI et al., 2002), and anthracene concentrations ranging from 3.55 to 24.4 $\mu \mathrm{g} . \mathrm{L}^{-1}$ have been found in pore water of the Jiulong River Estuary and in Western Xiamen Sea, China (MASKAOUI et al., 2002). Ren et al. (2010) monitored the PAH level of the surface seawater of the East and South China Seas by continuous sampling of seawater along the shipping lane and found that the concentration of anthrecene was $0.0083 \mathrm{mg} \cdot \mathrm{mL}^{-1}$, the highest among 16 priority PAHs investigated. In the northwestern part of the Japan Sea, Chizhova et al. (2013) reported the value of $0.34 \pm 0.06$ ng. $L^{-1}$. In seawater around England and Wales, Law et al. (1997) reported that the values varied from $<1$ to 157 ng. $\mathrm{L}^{-1}$. In the estuary around the cities of Cubatão and Santos, where the nearby industrial complex is found, the ANT concentration in the sediment can vary from 4.83 to $7.55 \mathrm{ng}^{-1} \mathrm{~g}^{-1}$ and can even reach $2,164 \mathrm{ng}^{-\mathrm{g}^{-1}}$ (BÍCEGO et al., 2006).

Our results clearly indicate that, in the absence of RUV, ANT is genotoxic to the coastal fish $T$. carolinus and that DNA damages, as seen from the comet assay, were dose- and depuration/timedependent. The absence of fish mortality during the study indicates that anthracene is not lethal to this species under experimental conditions. Exposure to anthracene for $24 \mathrm{~h}$ was sufficient to demonstrate the genotoxic effect of this PAH, as shown by the significant differences in the DIs of groups exposed to ANT as compared to those of the control groups. The high value of the DI in the groups exposed to ANT and subsequently maintained for $48 \mathrm{~h}$ in clean water may be related to the fact that this period was insufficient for $T$. carolinus to undergo depuration. The 96 hours were sufficient for fish from the $8 \mu \mathrm{g} . \mathrm{L}^{-1}$ group to depurate the ANT almost completely, and partially sufficient for the $16 \mu \mathrm{g} . \mathrm{L}^{-1}$ group. In the 32 $\mu \mathrm{g} . \mathrm{L}^{-1}$ group even $144 \mathrm{~h}$ was insufficient to bring about anthracene depuration. A similar duration for ANT depurations was found for other aquatic organisms. After exposure to ANT $\left(12 \mu \mathrm{g} . \mathrm{L}^{-1}\right)$ in the dark for $24 \mathrm{~h}, 144 \mathrm{~h}$ of depuration were necessary for Lepomis macrochirus to survive the subsequent period of exposure to UVR (BOWLING et al., 1983). Amphipods exposed to $16 \mu \mathrm{g} . \mathrm{L}^{-1}$ for $24 \mathrm{~h}$ survived 23 days in contact with UVR after $120 \mathrm{~h}$ of depuration (GOMES et al., 2009).

The high DIs in the group of fish maintained for $48 \mathrm{~h}$ in clean seawater may be related to the biotransformation of PAHs into potentially genotoxic intermediates such as ROS that interact with DNA promoting strand breaks in this molecule (VANZELLA et al., 2007). Vieira et al. (2008) suggested that ANT biotransformation is capable of promoting oxidative stress in Pomatoschistus microps. In their work, fish exposed for $96 \mathrm{~h}$ to the PAH solutions $\left(0.25,0.5,1,2\right.$ or $\left.4 \mu \mathrm{g} . \mathrm{L}^{-1}\right)$ showed an increased activity of enzymes, such as catalase, superoxide dismutase, glutathione reductase and glutathione peroxidase, which protect the fish from the oxidative damage caused by reactive oxygen species.

The reduction in DNA damage found after $96 \mathrm{~h}$ of depuration is evident in fish that were exposed to concentrations of 8 and $16 \mu \mathrm{g} . \mathrm{L}^{-1}$. Possible causes for this result may be the effect of the depuration of the ANT and the ability to repair DNA. This effect is more pronounced in fish submitted to the lowest concentration of ANT and that remained in clean water for the longest period, i.e., $144 \mathrm{~h}$. Their DNA damage decreased dramatically, reaching a DI value close to that of the control groups. The repair of DNA strand breaks in most cell types is a quick process that occurs within minutes and can be detected with the comet assay and other repair enzymes, such as the base excision performed by endonuclease-III (COLLINS, 2004). The capacity for DNA repair in fish after being submitted to genotoxic agents is known for several species. Phorate, an organophosphate pesticide, is genotoxic to Labeo rohita. Specimens contaminated by this pesticide when maintained in water free of pollution also showed the ability to repair DNA damage (MOHANTY et al., 2011). Using the comet assay, Groff et al. (2010) detected a reduction in DNA damage to the erythrocytes of Neotropical fish (Arapaima gigas and Colossoma macroporum) 12 hours after exposure to UVR-B (ultraviolet radiation B) and suggest that nucleotide excision repair is involved in DNA repair.

The increase in DNA damage in the 16 $\mu \mathrm{g} . \mathrm{L}^{1}$ group maintained for $144 \mathrm{~h}$ in clean water, as well as the occurrence of a large DI in the $32 \mu \mathrm{g} . \mathrm{L}^{-1}$ group over the three depuration periods, may be related to the concentrations employed. The two highest concentrations used, although they were sublethal within a $24 \mathrm{~h}$ exposure period, may have affected the physiological status of the animal so as to impair both the depuration ability and the DNA repair mechanism. Amado et al. (2006) found low activity of catalase and glutathione-S-transferase and extensive DNA damage in Micropogonias furnieri collected from polluted areas during the winter and suggest that 
these fish were subjected to pollutant levels sufficient to reduce immune activity and also profoundly to affect the mechanism of DNA repair, causing irreversible genetic damage.

The absence of mortality observed in our study, in the absence of UVR, corroborates previous data obtained on other fish species or cell cultures and also from other animals. ANT is not lethal either to Lepomis spp. exposed for $48 \mathrm{~h}$ to the $4,12,20$ or 28 $\mu \mathrm{g} . \mathrm{L}^{-1}$ concentrations or to Lepomis macrochirus exposed to ANT (12.7 $\left.\mu \mathrm{g} . \mathrm{L}^{-1}\right)$ or its photo-products for $72 \mathrm{~h}$ in darkness (BOWLING et al., 1983; ORIS; GIESY, 1985). ANT and two of its photo-products (anthraquinone and 1.2 - dihydroxiantraquinone) proved not to be not significantly toxic to the Poeciliopsis lucida hepatocyte cell line (PLHC-1) in the absence of UVR (CHOI; ORIS, 2003). In addition to these results, ANT has been shown not to be toxic to other organisms (mosquito larvae, water fleas, frog embryos or amphipods) when kept in the dark (KANGAN et al., 1985; GOMES et al., 2009).

In the present study, the DIs of fish from WCtrl and SCtrl maintained for 96 and $144 \mathrm{~h}$ in clean water were much lower than those in the groups exposed to ANT for the same periods. However, these DI were significantly higher than that for the $48 \mathrm{~h}$ period. This finding is probably related to the stress of staying in aquaria during the experiments.

This study shows also that $T$. carolinus can be used to evaluate the genotoxic effects of pollutants derived from petroleum. Rocha et al. (2012) showed that this fish suffered significant damage to its DNA after being fed with shrimp exposed to benzo(a)pyrene concentrations, thus reinforcing its usefulness for genotoxicity studies.

\section{Conclusion}

The present study demonstrated that anthracene exhibits genotoxicity to $T$. carolinus. This effect is dose dependent. Fish subjected to $8 \mu \mathrm{g} . \mathrm{L}^{-1}$ of ANT required $96 \mathrm{~h}$ for depuration, while those subjected to higher concentrations (16 and $32 \mu \mathrm{g} . \mathrm{L}^{-1}$ ) do not complete the depuration process even after 144 $\mathrm{h}$. The comet assay gave results consistent with expectations and reinforce its use as an effective tool for the analysis of pollutant action in DNA.

\section{ACKNOWLEDGEMENTS}

This study was supported by CAPES, CNPq, FAPESP (Process 2008/07824-0) and the Oceanographic Institute of the University of São Paulo. We wish to thank all the members of the Laboratory of Marine Life Ecophysiology.

\section{REFERENCES}

AKCHA, F.; HUBERT, F. V.; PFHOL-LESZKOWICZ, A. Potential value of the comet assay and DNA adduct measurement in dab (Limanda limanda) for assessment of in situ exposure to genotoxic compounds. Mutat. Res., v. 534, n. 1/2, p. 21-32, 2003.

AL-SABTI, K.; METCALFE, C. D. Fish micronuclei for assessing genotoxicity in water. Mutat. Res., v. 343, n. 2/3, p. 121-135, 1995.

AMADO, L. L.; ROSA, C. E.; LEITE, A. M.; MORAES, L.; PIRES, W. V.; PINHO, G. L. L.; MARTINS, C. M. G.; ROBALDO, R. B.; NERY, L. E. M.; MONSERRAT, J. M.; BIANCHINI, A.; MARTINEZ, P. E.; GERACITANO, L. A. Biomarkers in croakers Micropogonias furnieri (Teleostei: Sciaenidae) from polluted and non-polluted areas from the Patos Lagoon estuary (Southern Brazil): evidences of genotoxic and immunological effects. Mar. Pollut. Bull., v. 52, n. 2, p. 199-206, 2006.

BEDDING, N. D.; MCINTYRE, A. E.; PERRY, R.; LESTER, J. N. Organic contaminants in the aquatic environment. II. Behavior and fate in hydrological cycle. Sci. Total Environ., v. 26, p. 255-312, 1983.

BÍCEGO, M. C.; TANIGUCHI, S.; YOGUI, G. T.; MONTONE, R. C.; MOREIRA DA SILVA, D. A.; LOURENÇO, R. A.; CASTRO MARTINS, C.; SASAKI, S. T.; PELLIZARI, V. H.; WEBER, R. R. Assessment of contamination by polychlorinated biphenyls and aliphatic and aromatic hydrocarbons in sediments of the Santos and São Vicente Estuary System, São Paulo, Brazil. Mar. Pollut. Bull., v. 56, n. 12, p. 1804-1816, 2006.

BOWLING, J. W.; LEVERSEE, G. J.; LANDRUM, P. F.; GIESY, J. P. Acute mortality of anthracenecontaminated fish exposed to sunlight. Aquat. Toxicol., v. 3, n. 1, p. 79-90, 1983.

CHIZHOVA, T.; HAYAKAWA, K.; TISHCHENKO, P.; NAKASE, H.; KOUDRYASHOVA, YU. Distribution of PAHs in the northwestern part of the Japan Sea. Deep Sea Res., Part II,v. 86/87, pt. II, p. 19-24, 2013.

CHOI, J.; ORIS, J. T. Assessment of the toxicity of anthracene photo-modification products using the topminnow (Poeciliopsis lucida) hepatoma cell line (PLHC-1). Aquat. Toxicol., v. 65, n.3, p. 243-251, 2003.

COLLINS, A. R. The Comet assay damage for DNA and repair: principles, applications, and limitations. Mol. Biotechnol., v. 26, n. 3, p. 249-261, 2004.

COTELLE, S.; FÉRARD, J. F. Comet assay in genetic ecotoxicology: a review. Environ. Mol. Mutagen., v. 34, n. 4, p. 246-255, 1999.

CRABTREE, R. E.; HOOD, P. B.; SNODGRASS, D. Age, growth and reproduction of permit (Trachinotus falcatus) in Florida waters. Fish. Bull., v. 100, n. 1, p. 26-34, 2002.

DI GIULIO, R. T.; BENSON, W. H.; SANDERS, B. M.; VAN VELD, P. A. Biochemical mechanisms metabolism, adaptation and toxicity. In: RAND, G. M. (Ed.). Fundamentals of aquatic toxicology: effects, environmental fate, and risk assessment. 2.ed. Washington: Taylor \& Francis, 1995. p. 523-561. 
EUROPEAN CHEMICAL AGENCY. Support Document for Identification of Anthracene as a Substance of Very High Concern, 2008. 21 p. Available at: http://echa.europa.eu/documents/10162/13638/svhc_sup doc_anthracene_publication_en.pdf Accessed in: 14 mar. 2010 .

FRENZILLI, G.; NIGRO, A.; LYONS, B. P. The comet assay for the evaluation of genotoxic impact in aquatic environments. Mutat. Res., v. 681, n.1, p. 80-92, 2009. [Review].

GARCÍA, O.; MANDINA, T.; LAMADRID, A. I.; DIAZ A.; REMIGIO, A.; GONZALEZ, Y.; PILOTO, J.; GONZALEZ, J. E.; ALVAREZ, A. Sensitivity and variability of visual scoring in the comet assay: results of an inter-laboratory scoring exercise with the use of silver staining. Mutat. Res., v. 556, n. 1/2, p. 25-34, 2004.

GOMES, V.; PASSOS, M. J. A. C. R.; LEME, N. M. P.; SANTOS, T. C. A.; CAMPOS, D. Y. F.; HASUE, F. M.; PHAN, V. N. Photo-induced toxicity of anthracene in the Antarctic shallow water amphipod Gondogeneia antarctica. Polar Biol., v. 32, n. 7, p. 1009-1021, 2009.

GOMES, V.; PASSOS, M. J. A. C. R.; SANTOS, T. C. A.; CAMPOS, D. Y. F.; USSAMI, K. A.; HASUE, F. M. PHAN, V. N. DNA strand breaks in caged Antarctic coastal fishes (Trematomus newnesi), following exposure to the waters in front of the Brazilian Antarctic Research Station "Comandante Ferraz", King George Island. Pesqui. Antart. Bras., v. 5 p. 61-70, 2012.

GONTIJO, A. M. M. C.; TICE, R. Teste do cometa para a detecção de dano no DNA e reparo em células individualizadas. In: RIBEIRO, L. R.; SALVADORI, D. M. F.; MARQUES, E. K. (Orgs.). Mutagênese ambiental. Canoas: Ulbra, 2003. p. 247-279.

GROFF, A. A.; SILVA, J.; NUNES, E. A.; IANISTCKI, M.; GUECHEVA, T. N.; OLIVEIRA, A. M.; OLIVEIRA, C. P. F.; VAL, A. L.; HENRIQUES, J. A $\mathrm{P}$. UVA/UVB-induced genotoxicity and lesion repair in Colossoma macropomum and Arapaima gigas Amazonian fish. J. Photochem. Photobiol., B, v. 99, n. 2, p. 93-99, 2010.

HASEGAWA, M.; SUZUKI, A.; MATSUMURA, S.; TOSHIMA, K. Molecular design, chemical synthesis, and evaluation of novel anthracene derivatives as a new family of protein photocleavers. Sci. Technol. Adv. Mater., v. 7, n. 2, p. 169-174, 2006.

HATCH, A. C.; BURTON Jr., G. A. Photo-induced toxicity of PAHs to Hyalella azteca and Chironomus tentans: effects of mixtures and behavior. Environ. Pollut., v. 106, n.2, p. 157-167, 1999.

JORY, D. E.; IVERSEN, E. S.; LEWIS, R. H. Culture of the fishes of the genus Trachinotus (Carangidae) in the western Atlantic: prospects and problems. J. World Maric. Soc., v. 16, n. 1/4, p. 87-94, 1985.

KANGAN, J.; KAGAN, E. D.; KAGAN, I. A.; KAGAN, P. A.; QUIGLEY, S. The phototoxicity of non-carcinogenic polycyclic aromatic hydrocarbons in aquatic organisms. Chemosphere, v. 14, n. 11/12, p. 1829-1834, 1985.

KIENE, R. P.; CAPONE, D. G. Effects of organic pollutants on methanogenesis, sulfate reduction and carbon dioxide evolution in salt marsh sediments. Mar. Environ. Res., v. 13, p. 141-160, 1984.

LAW, R. J.; DAWES, V. J.; WOODHEAD, R. J.; MATTHIESSEN, P. Polycyclic Aromatic Hydrocarbons
$(\mathrm{PAH})$ in seawater around England and Wales. Mar. Pollut. Bull., v. 34, n. 5, p. 306-322, 1997.

LEE, R. F.; PAGE, D. S. Petroleum hydrocarbons and their effects in subtidal regions after major oil spills. Mar. Pollut. Bull., v. 34, n. 11, p. 928-940, 1997.

LEE, R. F.; STEINERT, S. Use of the singles cell electrophoresis/comet assay for detecting DNA damage in aquatic (marine and freshwater) animals. Mutat. Res., v. 544, n. 1 , p. $43-64,2003$.

MALlAKIN, A.; DIXON, D. G.; GREENBERG, B. M. Pathway of anthracene modification under simulated solar radiation. Chemosphere, v. 40, n. 12, p. 1435$1441,2000$.

MASKAOUI, K.; ZHOU, J. L.; HONG, H. S.; ZHANG, Z. L. Contamination by polycyclic aromatic hydrocarbons in the Jiulong River Estuary and Western Xiamen Sea, China. Environ. Pollut., v. 118, n.1, p. 109-122, 2002.

MCELROY, A. E.; FARRINGTON, J. W.; TEAL, J. M. Bioavailability of polycyclic aromatic hydrocarbons in the aquatic environment. In: VARANASI, U. (Ed.) Metabolism of polycyclic aromatic hydrocarbons in the aquatic environment. Boca Raton: CRC Press, 1989. p. 1-39.

MEDEIROS, P. M.; BÍCEGO, M. C. Investigation of natural and anthropogenic hydrocarbon inputs in sediment using geochemical markers. II. São Sebastião, SP-Brazil. Mar. Pollut. Bull., v. 49, n. 11-12, p. 892-899, 2004.

MEDEIROS, P. M.; BÍCEGO, M. C.; CASTELÃO, R. M.; DEL ROSSO, C.; FILMANN, G.; ZAMBONI, A. J. Natural and anthropogenic hydrocarbon inputs to sediments of Patos Lagoon Estuary, Brazil. Environ. Int., v. 31, n. 1, p. 77-87, 2005.

MENEZES, N. A.; FIGUEIREDO, J. L. Manual de peixes marinhos do sudeste do Brasil. IV. Teleostei 3. São Paulo: Museu de Zoologia da Universidade de São Paulo, 1980.96 p

MOHANTY, G.; MOHANTY, J.; NAYAK, A. K.; MOHANTY, S.; DUTTA, S. K. Application of comet assay in the study of DNA damage and recovery in rohu (Labeo rohita) fingerlings after an exposure to phorate, an organophosphate pesticide. Ecotoxicology, v. 20, n. 1, p. 283-292, 2011.

NEFF, J. M. Polycyclic aromatic hydrocarbons in the aquatic environment: sources, fates and biological effects. London: Applied Science Publishers, 1979. 262 $\mathrm{p}$.

NIANG, T. M. S., PESSANHA, A. L. M.; ARAÚJO, F. G. Dieta de juvenis de Trachinotus carolinus (Actinopterygii, Carangidae) em praias arenosas na costa do Rio de Janeiro. Iheringia, Ser. Zool., v. 100, n. 1, p. 35-42, 2010.

ORIS, J. T.; GIESY Jr., J. P. The photoenhanced toxicity of anthracene to juvenile sunfish (Lepomis spp.). Aquat. Toxicol., v. 6, n. 2, p. 133-146, 1985.

ORIS, J. T.; GIESY Jr., J. P. The photo-induced toxicity of polycyclic aromatic hydrocarbons to larvae of the fathead minnow (Pimephales promelas). Chemosphere, v. 16, n. 7, p. 1395-1404, 1987.

PACHECO, M.; SANTOS, M. A. Biotransformation, genotoxic, and histopathological effects of environmental contaminants in European eel (Anguilla anguilla L.). Ecotoxicol. Environ. Saf., v. 53, n. 3, p. 331-347, 2002. 
PELLETIER, E.; SARGIAN, P.; PAYET, J.; DEMERS, S. Ecotoxicological effects of combined UVB and organic contaminants in coastal waters: a review. Photochem. Photobiol., v. 82, n. 4, p. 981-993, 2006.

RAND, G. M. Fish toxicity studies. In: DI GIULIO, R. T.; HINTON, D. E. (Eds.). The toxicology of fishes. Boca Raton: CRC Press, 2008. p. 659-681.

REN, H.; KAWAGOE, T.; JIA, H.; ENDO, H.; KITAZAWA, A.; GOTO, S.; HAYASHI, T. Continuous surface seawater surveillance on poly aromatic hydrocarbons (PAHs) and mutagenicity of East and South China Seas. Estuarine, Coastal Shelf Sci., v. 86, n. 3, p. 395-400, 2010.

ROCHA, A. J. S.; SANTOS, T. C.; GOMES, V.; BÍCEGO, M. C.; BARBOSA, A. C. R. A.; PASSOS, M. J. A. C. R.; HASUE, F. M.; PHAN, V. N. Assessment of trophic transfer of benzo(a)pyrene genotoxicity from the postlarval pink shrimp $F$. brasiliensis to juvenile Florida pompano T. carolinus. Environ. Toxicol. Pharmacol. v. 34, n. 3, p. 969-976, 2012.

SANTOS, T. C. A.; PHAN, V. N.; PASSOS, M. J. A. C. R. GOMES, V. Effects of naphthalene on metabolic rate and ammonia excretion of juvenile Florida pompano, Trachinotus carolinus. J. Exp. Mar. Biol. Ecol., v. 335, n. 1, p. 82-90, 2006.

SCHIRMER, K.; CHAN, A. G. J.; GREENBERG, B. M.; DIXON, D. G.; BOLS, N. C. Ability of 16 priority PAHs to be photocytotoxic to a cell line from the rainbow trout Gill. Toxicology, v. 127, p. 143-155, 1998.

SINGH, N. P.; MCCOY, M. T.; TICE, R. R.; SCHNEIDER; E. L. A simple technique for quantitation of low level of DNA damage in individual cells. Exp. Cell Res., v. 175, n. 1, p. 184-191, 1988

TICE, R. R.; AGURELL, E.; ANDERSON, D. BURLINSON, B.; HARTMANN, A.; KOBAYASHI, H.; MIYAMAE, Y.; ROJAS, E.; RYU, J. C.; SASAKI, Y. F. Single cell gel/comet assay: guidelines for in vitro and in vivo genetic toxicology testing. Environ. Mol. Mutagen., v. 35, n. 3, p. 206-221, 2000.

TOSHIMA, K.; HASEGAWA, M.; SHIMIZU, J.; MATSUMURA, S. Molecular design, chemical synthesis and biological evaluation of anthracenecarbohydrate hybrids as novel DNA photocleaving and photoselective cytotoxic agents. ARKIVOC, v.2004, n.13, p. 28-35, 2004.
TOYOOKA, T.; IBUKI, Y. DNA damage induced by coexposure to PAHs and light. Environ. Toxicol. Pharmacol., v. 23, n. 2, p. 256-263, 2007.

ULUPINAR, M.; OKUMUS, I. Detection of mutageniccarcinogenic pollutants in aquatic system using cytogenetic methods in fish. Turk. J. Zool., v. 26, p. 141-148, 2002.

UNITED STATES. Department of Health and Human Services. Public Health Services. Agency for Toxic Substances and Disease Registry. Toxicological profile for polycyclic aromatic hydrocarbons. Atlanta: Agency for Toxic Substances and Disease Registry, 1995. $30 \mathrm{p}$.

VANZELLA, T. P.; MARTINEZ, C. B. R.; CÓLUS, I. M. S. Genotoxic and mutagenic effects of diesel oil water soluble fraction on a neotropical fish species. Mutat. Res., v. 631, n. 1, p. 36-43, 2007.

VIEIRA, L. R.; SOUSA, A.; FRASCO, M. F.; LIMA, I.; MORGADO, F.; GUILHERMINO, L. Acute effects of Benzo[a]pyrene, anthracene and a fuel oil on biomarkers of the common goby Pomatoschistus microps (Teleostei, Gobiidae). Sci. Total Environ., v. 395, n. 2/3, p. 87-100, 2008.

VIGURI, J.; VERDE, J.; IRABIEN, A. Environmental assessment of polycyclic aromatic hydrocarbons (PAHs) in surface sediments of the Santander Bay, Northern Spain. Chemosphere, v. 48, n. 2, p. 157-165, 2002.

ZAR, J. H. Biostatistical analysis. 3.ed. Upper Saddle River: Prentice-Hall, 1996. 918 p.
(Manuscript received 18 October 2012; revised 28 November 2013; accepted 06 December 2013) 